\title{
Composite spatial indexing of regional habitat importance
}

\author{
W. Myers ${ }^{1}$, J. Bishop $^{1}$, R. Brooks ${ }^{1}$ and G.P. Patil ${ }^{2}$ \\ ${ }^{1}$ School of Forest Resources, Pennsylvania State University, Univ. Park, PA 16802, USA \\ ${ }^{2}$ Dept. of Statistics, Pennsylvania State University, Univ. Park, PA 16802, USA
}

Keywords: Biodiversity, Conservation, GAP Analysis, GIS.

\begin{abstract}
Indexing and mapping of co-occurrence for multiple species is central to many analyses of conservation needs, ecosystem health, and community composition. Species richness is often used because of its simplicity and interpretability, but a variety of ecologically based weighting schemes for species have been developed for special purposes such as determining biotic integrity. This work is concerned with indexing a balance between common and uncommon species for preliminary assessments of conservation needs. A Regional Habitat Importance Index is constructed in a manner that provides joint ordering of species and landscapes. The index lends emphasis to species having a scarcity of habitat over a region, low representation in conservation areas, and shortage of opportunity for expanding protection. Application of the index is illustrated for mammals and birds in the context of GAP Analysis for the state of Pennsylvania, USA.
\end{abstract}

Abbreviation: RHII - Regional Habitat Importance Index.

\section{Introduction}

Quantitative indication of multiple co-occurrences is fundamental to analysis of biodiversity as well as ecological community studies. In such investigations, spatial scale is a matter of proximity within which co-occurrence is recognized (Wiens 1989, Loehle \& Wein 1994, Rosenzweig 1995). The simplest index of co-occurrence for multiple kinds of organisms is the familiar and much used species richness (Angermeier and Karr 1994, Myers et al. 2000, Samson and Knopf 1993, Shepard 1998), being a count of selected species present in the spatial scope of tally. Species richness is typically used for comparative purposes in finding and monitoring hotspots of biodiversity in a region of interest (Curnutt et al. 1994, Harcourt 2000, Reid 1998).

Species are not necessarily of equal interest, however, relative to ecosystem health and conservation planning. Habitat generalist species and those particularly adapted to environs of human habitation are of lesser concern for conservation, and may even be indicative that ecosystem integrity is degraded; whereas, relatively rare species and those belonging to particular functional groups (guilds) are of greater interest for conservation and assessment of ecosystem health (Bradford et al. 1998, Noss and Cooperrider 1994, Pimm and Lawton 1998, Prendergast et al.
1993, Williams et al. 1996). This leads to need for using weights as a means of incorporating species into composite indices that reflect particular aspects of ecosystem status such as biotic integrity (Brooks et al. 1998, O'Connell et al. 1998). In this context, our purpose is to present formulation of a Regional Habitat Importance Index for biodiversity assessment and results of its application with respect to vertebrate distributions in the state of Pennsylvania, USA.

\section{Mapping of potential habitat and its stewardship status}

A U.S. nationwide program of biodiversity assessment known as GAP Analysis provides the motivation and opportunity for our work (Scott et al. 1993). GAP Analysis is a coarse scale geographic approach to conservation that relies heavily on computer-based geographic information systems (GIS) and related information technologies (Davis et al. 1990, Olivieri and Backus 1992). GAP Analysis uses remotely sensed data in combination with various layers of map information and spatially specific databases along with knowledge-based models of biological characteristics for each species to arrive at mappings of potential habitat. Conservation stewardship status of habitat is then considered according to land ownership and mode of management. The overall objective is 
to identify 'gaps' in the conservation 'safety net' for maintenance of biological diversity. Such GAP mappings provide a 'coarse filter' input to more comprehensive planning for extension and establishment of reserve systems and/or promotion of cooperation between public and private interests to further the goals of conservation (Kiester et al. 1996, Pressey et al. 1993). GAP Analysis focuses attention on vertebrates under the assumption that habitat needs of macro-organisms will also serve to a large extent as surrogates for those of other organisms. Both common and rare species are considered, because the former includes keystone species for major regional habitats.

GAP Analysis typically uses vegetation community types as a principal differentiating factor for habitats. However, the complex intermixtures of forest tree species in Pennsylvania could not be reliably differentiated from satellite-based remotely sensed imagery having 30-meter resolution (Myers et al. 2000). Therefore, habitat mapping was done on the basis of several physiographic and landscape characteristics in conjunction with generalized land-cover maps. Habitat models were developed as matrices in the form of spreadsheets with columns representing habitat variables and rows representing species. The model for each species was then translated into a map by a sequence of conditional GIS operations designed to identify habitat and eliminate non-habitat areas.

Habitat variables in the matrix models for birds, mammals, amphibians, and reptiles were coded as integer numbers ranging from 1 to 4 which rate the variable as to its relevance for the particular species. The code designations were: 1 = habitat factor required by the species (primary use); 2 = habitat factor may be used by the species (secondary use); 3 = habitat factor avoided by the species; $4=$ factor not relevant to the species. Habitat maps for these groups were produced as cellular (raster) grids having 30-meter resolution.

The approach used for modeling of fishes was analogous, but differed in several respects. Fish habitat modeling was conducted in GIS polygon (vector) mode with the foundation layer comprised of 9,855 small watersheds for named streams in Pennsylvania. Variables for habitat models were attached directly to each watershed as tabular attributes in the GIS. Habitat factors included physiographic units, major river basins, stream size class, median slope, and extent of disturbance. Species profiles for habitat factors determine whether a watershed is primary habitat, secondary habitat, or non-habitat.

Many Pennsylvania vertebrate species have range restrictions that are not directly tied to local habitat factors, which may be due to climatic influence or historical circumstance. Early in the Pennsylvania GAP Project, The Nature Conservancy compiled a database of species ranges for Pennsylvania. Based on current and historic information, species presence was tabulated in each of 211 cells of a hexagonal lattice that had been configured as a sampling frame by the U.S. Environmental Protection Agency. Each hexagon encompasses an area of $635 \mathrm{~km}^{2}$. All hexagons that contained records for a particular species formed its preliminary range. Single hexagons constituting holes in the preliminary range were then incorporated for purposes of the Pennsylvania GAP Project. The (augmented) hexagon range was coupled with a GIS map layer delimiting small watersheds in order to select all watersheds having included centers. Boundaries among the selected watersheds were then dissolved to obtain a range modifier for the respective habitat model. Any potential habitat from modeling that fell outside this range was suppressed.

The status of conservation stewardship was mapped over the state in four classes. GAP status 1 includes designated wilderness areas, state forest natural areas, state forest wild areas, and fee-simple holdings of conservancies. GAP status 2 includes national wildlife refuges, state parks, state forests, state gamelands, state scenic rivers, and conservancy easements. GAP status 3 includes national forest, national cultural and historic parks, national recreation areas, and national scenic/recreational river segments. The remaining lands whether public or private having no known long-term provisions for conservation were classified as GAP status 4 . Conservation is a primary long-term consideration on status 1 lands, whereas it is at best a short-term consideration for status 4 lands.

\section{Methodology of regional habitat importance index}

Overlaying maps of potential habitat for the several species or groups of species will yield mappings of (potential) habitat richness that can be interpreted as modelbased species richness. By segregating conservation stewardship status 4 , the analysis locates substantial sectors of species-rich habitat types with weak stewardship as possible 'gaps' for further consideration in conservation planning. Since Pennsylvania has a large number of nearly ubiquitous vertebrate species, however, it was deemed inadequate to leave the matter of counterbalancing common and uncommon species to subjective interpretation.

It is important to have a relatively objective way of analyzing model results to determine which species face particular scarcity of sustainable habitat and where there 
Table 1. Ordering of Pennsylvania mammals relative to RHII, with - - marking the upper quartile.

\begin{tabular}{clll}
\hline RHII & Common name & Scientific name & Rank/Status \\
\hline 96 & E. spotted skunk & Spilogale putorius & SH \\
94 & Evening bat & Nycticeius humeralis & \\
90 & Least shrew & Cryptotis parva & S1, PE \\
88 & Rock vole & Microtus chrotorrhinus & S2 \\
81 & Indiana myotis & Myotis sodalis & G2, SUB,S1N, \\
& & & PE \\
66 & Elk & Cervus canadensis & Reintroduced \\
58 & Appalachian cottontail & Sylvilagus obscurus & SU \\
57 & N. water shrew & Sorex palustris & S3 \\
51 & Fisher & Martes pennanti & Reintroduced \\
46 & E. mole & Scalopus aquaticus & \\
44 & River otter & Lutra canadensis & Reintroduced \\
38 & Fox squirrel & Sciurus niger & SU \\
35 & Least weasel & Mustela nivalis & S3 \\
28 & Allegheny woodrat & Neotoma magister & S3, PT \\
$-23-$ & Snowshoe hare & Lepus americanus & \\
16 & Longtail shrew & Sorex dispar & S3 \\
\hline
\end{tabular}

is notable co-occurrence of such problematic species. To meet this need, a Regional Habitat Importance Index (RHII) was formulated for joint ordering of species and landscapes with regard to comparative availability of potential habitat. The index combines overall scarcity of habitat with scarcity of habitat in conservation areas and scarcity of habitat outside conservation areas. It lends particular emphasis to species that couple overall habitat scarcity with low representation in conservation areas and difficulty of finding suitable habitat outside existing conservation areas by which to enhance the level of protection. The index was formulated for Pennsylvania GAP Analysis as follows:

\section{RHII $=100 \times($ statewide proportion of non-habitat $)$ \\ $\times$ (proportion of non-habitat in conservation lands) \\ $\times$ (proportion of non-habitat outside conservation lands).}

Conservation lands were considered to be those having stewardship status 3 or better. Status 4 lands comprised the outside area.

When there are millions of cells in each map, it is not a trivial undertaking to compile a weighted composite of 470 maps for species of vertebrates that reproduce in Pennsylvania. Therefore, the matter of scale becomes an important consideration. Since the results of GAP Analysis are most reliably interpreted at landscape scale, a cell size for tabulation of $1 \mathrm{~km}^{2}$ was chosen as being both appropriate and manageable. A species was considered to have potential occurrence at the kilometer scale if any finer scale cells representing potential habitat were contained.

In anticipation that different general life history scenarios could find expression in spatial pattern, the RHII analysis was performed separately for six taxonomic groups: mammals, birds, amphibians, snakes \& lizards, turtles, and fishes. The 118,218 one-kilometer cells were configured as vector polygons with stewardship status as one of the entries in the attribute table. A supplemental attribute table was constructed for each group showing suitability of cells as rows for species as columns. The respective group table was joined to the general attribute table, and a series of table-based queries was used to obtain terms of the RHII for each species as entries in another table of RHII by species. Linkage of the latter table enabled cell-by-cell summation with GIS of RHIIs for all species of a group. The summation as RHII for the cell was then entered as a column for each taxonomic group in the main cellular attribute table.

\section{Application for mammals and birds in Pennsylvania}

The Pennsylvania RHII results for mammals and birds serve to illustrate the effectiveness of the formulation for the intended purpose as compared to simple species richness. Of the six taxonomic groups studied, these two are chosen for presentation because their contrasting patterns show the importance of separate analysis for different types of life histories. The RHII tables for species include rating status for species of special concern (Brauning et al. 1994, Genoways and Brenner 1985, Hassinger et al. 1998) as evidence that high RHII is reflective of conservation issues.

Table 1 contains a partial ordering of Pennsylvania mammals according to the RHII approach. This table goes one species below the upper quartile with regard to RHII. The eastern mole is somewhat anomalous with respect to this ordering, being confined to southeastern Pennsylvania by its lack of ability to move beyond hospi- 
Table 2. Ordering of Pennsylvania birds relative to RHII, with - - marking the upper quartile.

\begin{tabular}{|c|c|c|c|}
\hline RHII & Common name & Scientific name & Rank/Status \\
\hline 100 & Black-necked stilt & Himantopus mexicanus & \\
\hline 99 & Yellow-bellied flycatcher & Empidonax virescens & S1, S2B, PT \\
\hline 99 & Black tern & Chlidonias niger & $\mathrm{S} 1 \mathrm{~B}, \mathrm{PE}$ \\
\hline 99 & Blackpoll warbler & Dendroica striata & \\
\hline 98 & Short-eared owl & Asio flammeus & S1B, S3N, PE \\
\hline 98 & Dickcissel & Spiza americana & S2B \\
\hline 97 & American wigeon & Anas americana & \\
\hline 97 & Peregrine falcon & Falco peregrinus & $\mathrm{S} 1 \mathrm{~B}, \mathrm{~S} 1 \mathrm{~N}, \mathrm{PE}$ \\
\hline 97 & Great egret & Ardea alba & \\
\hline 96 & Clay-colored sparrow & Spizella pallida & \\
\hline 95 & Swainson's warbler & Limnothlypis swainsonii & \\
\hline 95 & N. shoveler & Anas clypeata & \\
\hline 94 & Snowy egret & Egretta thula & \\
\hline 94 & King rail & Rallus elegans & S1B, PE \\
\hline 93 & Cattle egret & Bulbulcus ibis & \\
\hline 93 & Chuck-will's-widow & Caprimulgus carolinensis & \\
\hline 90 & Marsh wren & Cistothorus palustris & S2, S3B \\
\hline 90 & Loggerhead shrike & Lanius ludovicianus & S1B, PE \\
\hline 90 & Yellow-crowned night-heron & Nycticorax violaceus & \\
\hline 90 & Mute swan & Cygnus olor & Exotic \\
\hline 89 & N. waterthrush & Seiurus noveboracensis & \\
\hline 89 & Olive-sided flycatcher & Contopus borealis & S1B \\
\hline 87 & Sedge wren & Cistothorus platensis & S1B, PT \\
\hline 84 & Winter wren & Troglodytes troglodytes & \\
\hline 80 & Green-winged teal & Anas crecca & S1, S2B, S3N \\
\hline 81 & Bald eagle & Haliaeetus leucocephalus & S1, S2B, PE \\
\hline 80 & American coot & Fulica americana & S3B, S3N \\
\hline 79 & Summer tanager & Piranga rubra & S3B \\
\hline 77 & Long-eared owl & Asio otus & S2B, S2S3N \\
\hline 77 & Common snipe & Gallinago gallinago & S3B, S3N \\
\hline 75 & Least bittern & Ixobrychus exilis & S1B, PT \\
\hline 66 & Prothonotary warbler & Protonotaria citrea & \\
\hline 66 & American bittern & Botaurus lentiginosus & S1B, PT \\
\hline 66 & Upland sandpiper & Bartramia longicauda & S1S2B, PT \\
\hline 65 & Swainson's thrush & Catharus ustulatus & S2S3B, S5N, PT \\
\hline 63 & Blue grosbeak & Guiraca caerulea & \\
\hline 60 & Hooded merganser & Lophodytes cucullatus & \\
\hline 58 & Golden-crowned kinglet & Regulus satrapa & \\
\hline 56 & Blue-winged teal & Anas discors & \\
\hline 56 & Common moorhen & Gallinula chloropus & S3B \\
\hline 53 & Blue-headed vireo & Vireo solitarius & \\
\hline 53 & Pied-billed grebe & Podilymbus podiceps & S3B, S4N \\
\hline 53 & Black-crowned night-heron & Nycticorax nycticorax & S2S3B \\
\hline 48 & Dark-eyed junco & Junco hyemalis & \\
\hline$-46-$ & Yellow-throated vireo & Vireo flavifrons & \\
\hline 45 & Common merganser & Mergus merganser & \\
\hline
\end{tabular}

table soils. This is a reminder that all such indexed orderings do require professional interpretation. For instance, the index will equally well highlight the occurrence of newly introduced exotics that could subsequently become invasive.

Table 2 contains an ordering of Pennsylvania bird species according to RHII. This table goes one species below the upper quartile with regard to RHII. It is notable that the majority of species in the upper quartile have a wetland affinity of some kind. There are also several species associated with grassland habitats. Thus, it implies that further conservation focus is warranted for avifauna in these landscape settings. There are two anomalous spe- cies in this list with respect to implications for conservation. One is the black-necked stilt at the top of list, which represents only a single pair known to nest regularly around a sewage treatment facility in southeastern Pennsylvania. The other is the mute swan that is a rather aggressive exotic species having become established as a breeder.

Pennsylvania encompasses three major physiographic components. The Piedmont in southeastern Pennsylvania is a remnant plateau complex giving rise to fertile soils and moderate topography. Agricultural and urbanized developments are the primary land uses. Remaining forests in this region are restricted mostly to the more rugged 
uplands where relatively resistant parent materials produce shallower soils and to wetland areas that are problematic for both agriculture and development. The southeast portion of the Piedmont contains higher elevations than the more northerly and westerly components.

The Ridge and Valley region arches around the Piedmont through south-central and east-central Pennsylvania, with one finger extending northeast forming the heavily urbanized and extensively mined Wyoming Valley and another finger extending south of the Pocono Mountains to the Delaware River. The Ridge and Valley region consists primarily of the strongly folded ridge systems of the Appalachian Mountains, with an extensive Great Valley bordering the Piedmont. The mountains are interlaced ridges as remnant sides of much higher arches. Through time the centers eroded as a consequence of fracturing at the top of the fold. The forested ridges are rocky with thin infertile soils, thus being inhospitable to both agriculture and development as well as barriers to transportation. Soil fertility increases as one moves into the valleys, particularly where limestone parent material is found. The prominent mountain ridges separate sequences of narrow anticlinal and broader synclinal valleys. Agriculture is the dominant land use in the broad valleys, along with numerous urbanized developments.

The most extensive physiographic area is the Appalachian Plateau region, covering most of western and northern Pennsylvania. A thick horizontal layer of resistant sandstone is the major formative element of the region. The resistant sandstone generally weathers slowly resulting in shallow, infertile soils that are more suited to forests than to agriculture. The sandstones of the plateau contain inter-bedded shales that are more easily eroded, giving rise to differential dissection. Glaciation in the northern portions has contributed further to differentiation of this region and occurrence of more abundant wetlands. Stripmining is frequent on the plateau. Whereas the rugged northcentral portion is heavily forested, the more moderate topography of the western portion has enabled considerable fragmentation by localized small-scale agriculture and various developments including the Pittsburgh major metropolitan area.

Pennsylvania touches on large water bodies in the northwest and southeast corners. Lake Erie as one the freshwater Great Lakes is situated to the northwest, and the saltwater environment of the Delaware Bay lies to the southeast. There are major river systems in both eastern and western Pennsylvania. The Susquehanna and Delaware Rivers are prominent features of the Atlantic Slope. The Allegheny-Monongahela-Ohio River complex is prominent in western Pennsylvania.

Figure 1 is a one-kilometer scale mapping of Pennsylvania showing areas having mammal species richness above the median for major physiographic regions. The importance of minimally fragmented forest environments is evident, as is also the deleterious influence of human dominated landscapes.

A comparative view in terms of Regional Habitat Importance Index is provided in Figure 2. Areas of importance are much more clearly defined and coherent than is the case for simple species richness. Additionally, RHII lends emphasis to certain areas in and along the Ridge and Valley that are either not evident or weakly so in terms of

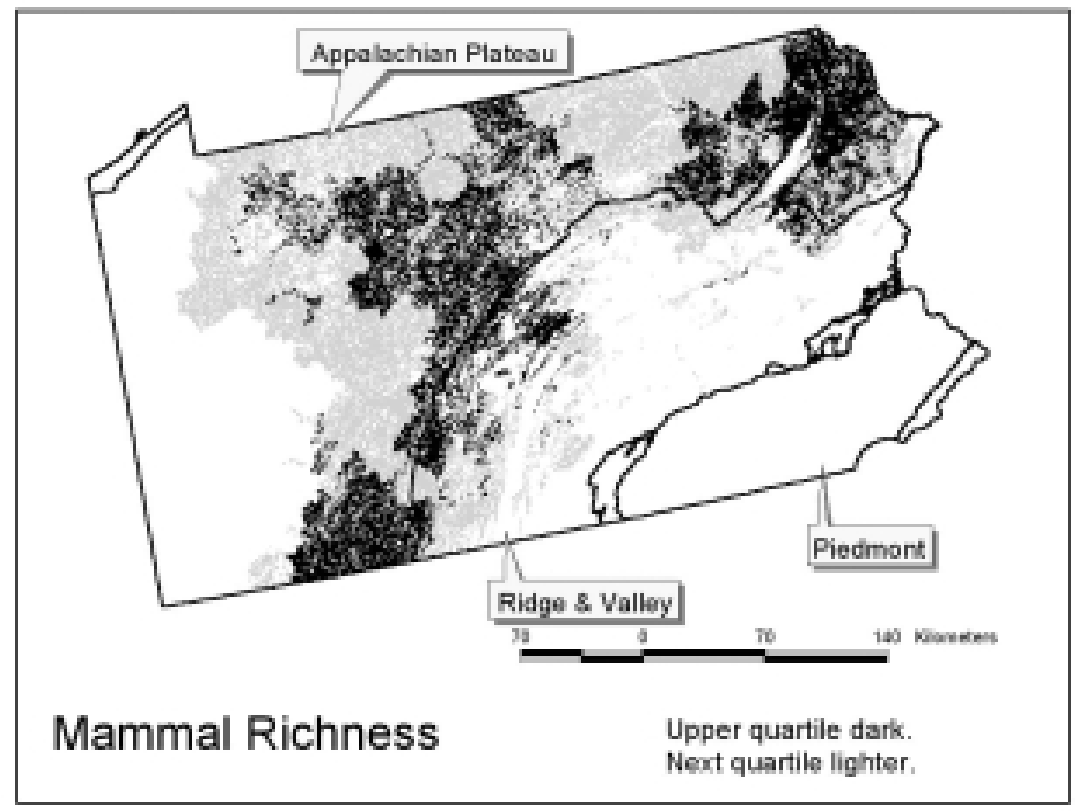

Figure 1. One-kilometer scale mapping of Pennsylvania showing areas having mammal species richness above the median. The upper quartile appears dark, and the next quartile lighter. Major physiographic regions are indicated. 
Figure 2. One-kilometer scale mapping of Pennsylvania showing areas above the median for mammals in terms of Regional Habitat Importance Index. The upper quartile appears dark, and the next quartile lighter. Major physiographic regions are indicated.

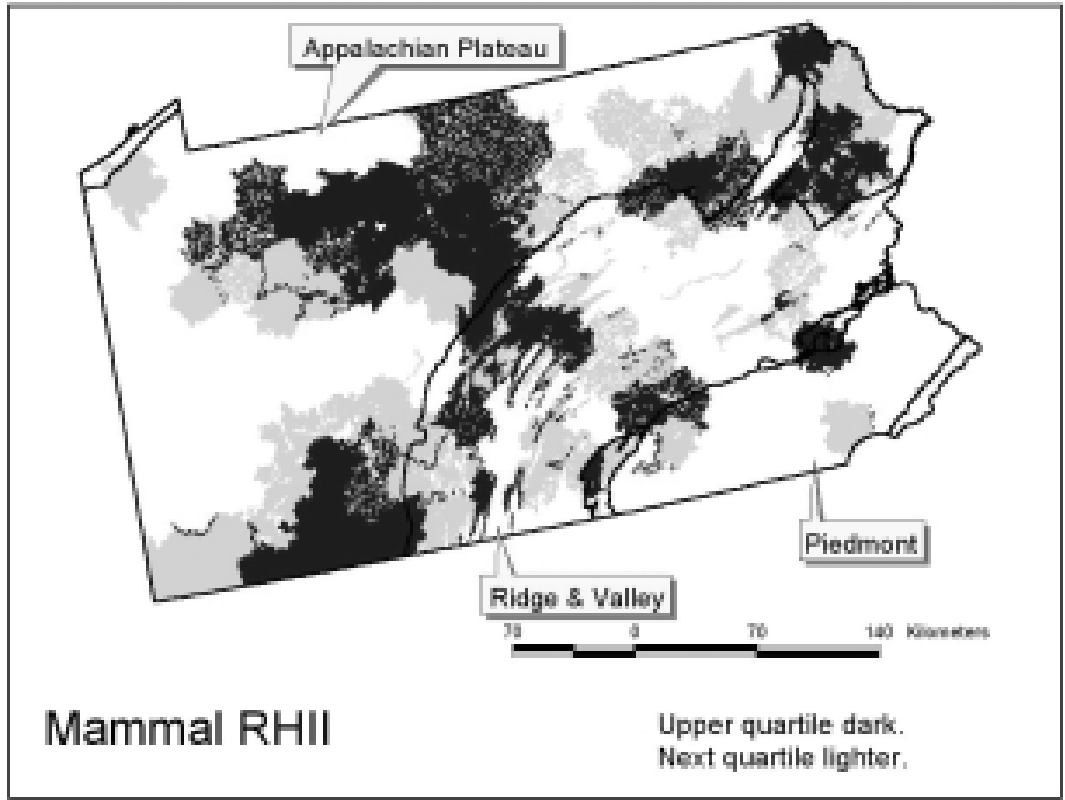

Figure 3. One-kilometer scale mapping of Pennsylvania showing areas having bird species richness above the median. The upper quartile appears dark, and the next quartile lighter. Major physiographic regions are indicated.

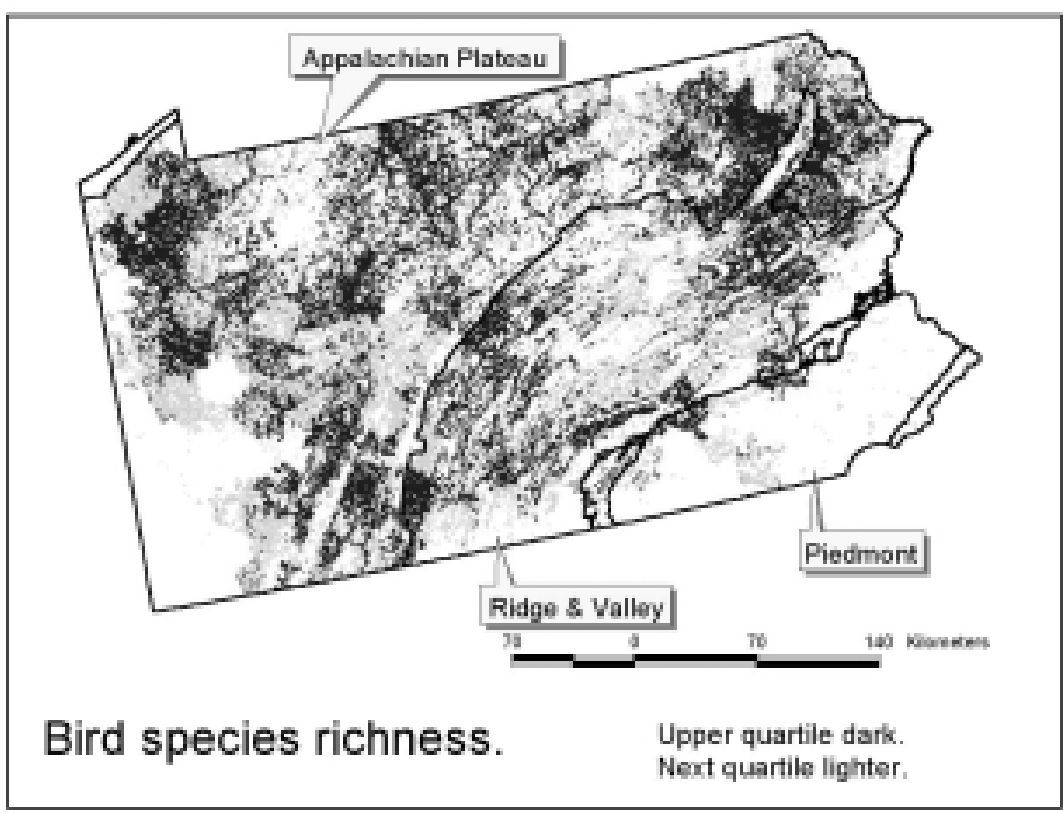

species richness. It is noteworthy that several areas highlighted by RHII are situated along the junctures of physiographic regions where species characteristic of both environments contribute jointly to biodiversity. It is apparent that RHII gives much more coherent signals for conservation perspectives than does conventional species richness.

Birds exhibit a wider spectrum of life history scenarios than mammals, thus offering a good comparative for exploring sensitivity of RHII and determining whether biodiversity assessments should be specific to ecological groupings of organisms. Figure 3 is a mapping of high bird species richness as a counterpart to Figure 1 for mam- mals. Bird species richness is much more geographically diffuse than for mammals. The overall importance of river valleys is seen in the Appalachian Plateau area where this influence transcends that of deep forest habitats. However, the importance of landscape diversity becomes more evident in the Ridge and Valley where ridgetop forests become refuges for forest-dwellers in otherwise human dominated landscapes. Heavily human dominated landscapes appear as inhospitable to avian biodiversity. Note particularly the apparent paucity of avian presence in the Piedmont.

Figure 4 is an avian counterpart map of RHII to that for mammals in Figure 2. In the case of birds, RHII pre- 

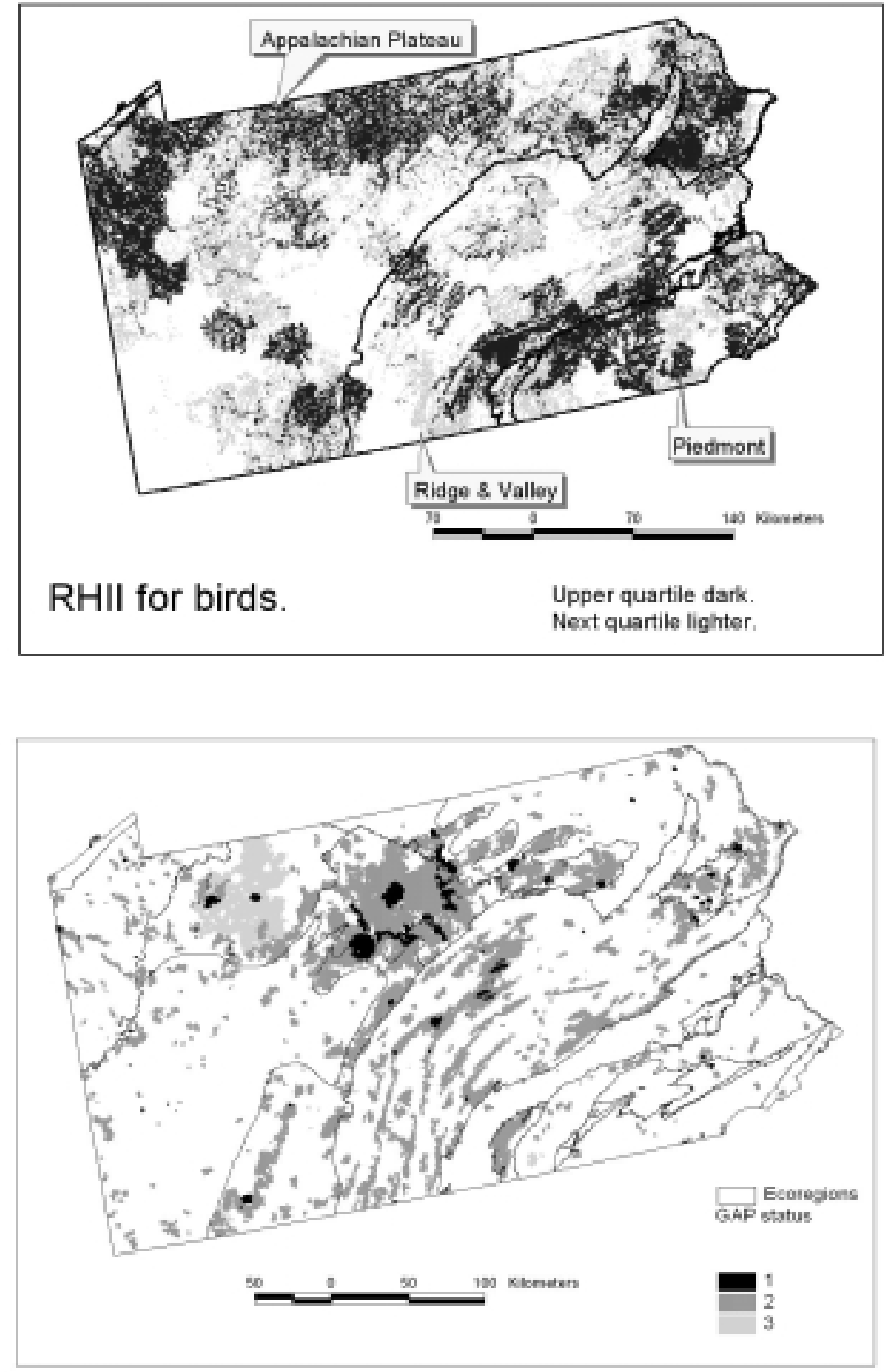

Figure 4. One-kilometer scale mapping of Pennsylvania showing areas above the median for birds in terms of Regional Habitat Importance Index. The upper quartile appears dark, and the next quartile lighter. Major physiographic regions are indicated.

Figure 5. Distribution of GAP land stewardship status in Pennsylvania, with further detail of ecoregion components in physiographic provinces. Shading indicates conservation status with darkest being fully protected (natural areas), and lighter having less restrictive habitat management. sents a substantially different picture than species richness. Areas of emphasis are much less diffuse than for species richness. More importantly, however, the large order river drainages of the Piedmont and southeastern Ridge and Valley become very prominent; whereas they appeared essentially devoid of interest relative to species richness. This is consistent with the high RHII ratings for wetland bird species in Table 2. From a conservation perspective, upland birds appear to be relatively well situated in Pennsylvania; as compared to wetland birds that appear quite vulnerable to habitat loss. Given the current distri- bution of land stewardship status in Pennsylvania as depicted in Figure 5, this becomes to be a valid perception. This is not to imply that deep forest habitats for neotropical migrants are unimportant, but that their habitats are much better protected than those of large riverine landscape settings. There is also considerable discrepancy between focal areas for birds versus mammals.

\section{Synthesis}

Reliance on broad taxonomic groupings and simple species richness for regional biodiversity assessments is 
clearly unwise. Coarse scale analyses using cost-efficient spatial information technologies and knowledge-based, landscape-level modeling of habitat requirements for individual species can present consistent and coherent regional conservation perspectives through objective index formulations. A Regional Habitat Importance Index (RHII) taking into account habitat scarcity and prior protection can provide a dual ordering of species and landscapes with respect to provisions for sustainability. The efficacy of the approach is demonstrated in Pennsylvania, USA as regional of considerable physiographic variability. Although not demonstrated here, the resulting compilations can be queried inversely to determine which species are most influential in generating high importance ratings for a given area. Regional habitat importance mappings for several groups of organisms can likewise be superimposed via GIS to locate zones of compound importance.

\section{References}

Angermeier, P. L. and J. R. Karr. 1994. Biological integrity versus biological diversity as policy directives: protecting biotic resources. Bioscience 44: 690-697.

Bradford, D. F., S. E. Franson, G. R. Miller, A. C. Neale, G. E. Cantebury and D. T. Heggen. 1998. Bird species assemblages as indicators of biological integrity in Great Basin rangeland. Environmental Monitoring and Assessment 49: 1-22.

Brauning, D. W., M. C. Brittingham, D. A. Gross, R. C. Leberman, T. L. Master and R. S. Mulvihill. 1994. Pennsylvania breeding birds of special concern: A list rationale and status update. Journal of the Pennsylvania Academy of Science 68: 3-28.

Brooks, R. P., T. J. O’Connell, D. H. Wardrop and L. E. Jackson. 1998. Towards a regional index of biological integrity: The example of forested riparian ecosystems. Environmental Monitoring and Assessment 51: 131-143.

Curnutt, J., J. Lockwood, H. Luh, P. Nott and G. Russell. 1994. Hotspots and species diversity. Nature 367: 326-327.

Davis, F. W., D. M. Stoms, J. E. Estes, J. Scepan and J. M. Scott 1990. An information systems approach to biological diversity. International Journal of Geographic Information Systems 4: 5578.

Genoways, H. H. and F. J. Brenner. 1985. Species of Special Concern in Pennsylvania. Carnegie Museum of Natural History, Pittsburgh, PA.

Harcourt, A. H. 2000. Coincidence and mismatch of biodiversity hotspots: a global survey for the order, primates. Biological Conservation 93: 163-175.

Hassinger, J. D., R. J. Hill, G. L. Storm and R. H. Yahner (eds.) 1998 Inventory and Monitoring of Biotic Resources in Pennsylvania. Pennsylvania Biological Survey, Harrisburg, PA.
Kiester, A. R., J. M. Scott, B. Csuti, R. F. Noss, B. Butterfield, K. Sahr and D. White. 1996. Conservation prioritization using GAP data. Conservation Biology 10: 1332-1342.

Loehle, C. and G. Wein. 1994. Landscape habitat diversity: a multiscale information theory approach. Ecol. Model. 73: 311-329.

Myers, N., R. A. Mittermeier, C. G. Mittermeier, G. A. B. da Fonseca and J. Kent. 2000. Biodiversity hotspots for conservation priorities. Nature 403: 853-858.

Myers, W., J. Bishop, R. Brooks, T. O’Connell, D. Argent, G. Storm, J. Stauffer, Jr. and R. Carline. 2000. The Pennsylvania GAP Analysis Final Report. 2000. The Pennsylvania State University, Univ. Park, PA 16802.

Noss, R. F. and A. Y. Cooperrider. 1994. Saving Nature's Legacy Island Press, Washington, D. C.

O’Connell, T. J., L. E. Jackson and R. P. Brooks. 1998. A bird community index of biotic integrity for the Mid-Atlantic Highlands. Environmental Monitoring and Assessment 51: 145-156.

Olivieri, S. T. and E. H. Backus. 1992. Geographic information systems (GIS) applications in biological conservation. Biology International 25: 10-16.

Pimm, S. L. and J. Lawton. 1998. Planning for biodiversity. Science 279: 2068-2069.

Prendergast, J. R., R. M. Quinn, R. M. Lawton, B. C. Eversham and D. W. Gibbons. 1993. Rare species, the coincidence of diversity hotspots and conservation strategies. Nature 365: 335-337.

Pressey, R. L., C. J. Humphries, C. R. Margules, R. I. Vane-Wright and P. H. Williams. 1993. Beyond opportunism: key principles for systematic reserve selection. Trends in Ecology and Evolution 8: 124-128.

Reid, W. V. 1998. Biodiversity hotspots. Trends in Ecology and Evolution 13: 275-280.

Rosenzweig, M. L. 1995. Species Diversity in Space and Time. Cambridge University Press, UK.

Samson, F. B. and F. L. Knopf. 1993. Managing biological diversity Wildlife Society Bulletin 21: 509-514.

Scott, J. M., F. Davis, B. Custi, R. Noss, B. Butterfield, C. Groves, H. Anderson, S. Caicco, F. D’Erchia, T. C. Edwards, Jr., J. Ulliman and R. G. Wright. 1993. Gap Analysis: a geographic approach to protection of biological diversity. Wildlife Monographs No. 123.

Shepard, U. L. 1998. A comparison of species diversity and morphological diversity across the North American latitudinal gradient. J. Biogeogr. 25: 19-29.

Wiens, J. A. 1989. Spatial scaling in ecology. Funct. Ecol. 3: 385397.

Williams, P., D. Gibbons, C. Margules, A. Rebelo, C. Humphries and R. Pressey. 1996. A comparison of richness hotspots, rarity hotspots, and complimentary areas for conserving diversity of British birds. Conservation Biology 10: 155-174. 